\title{
WATER BOATMEN
}

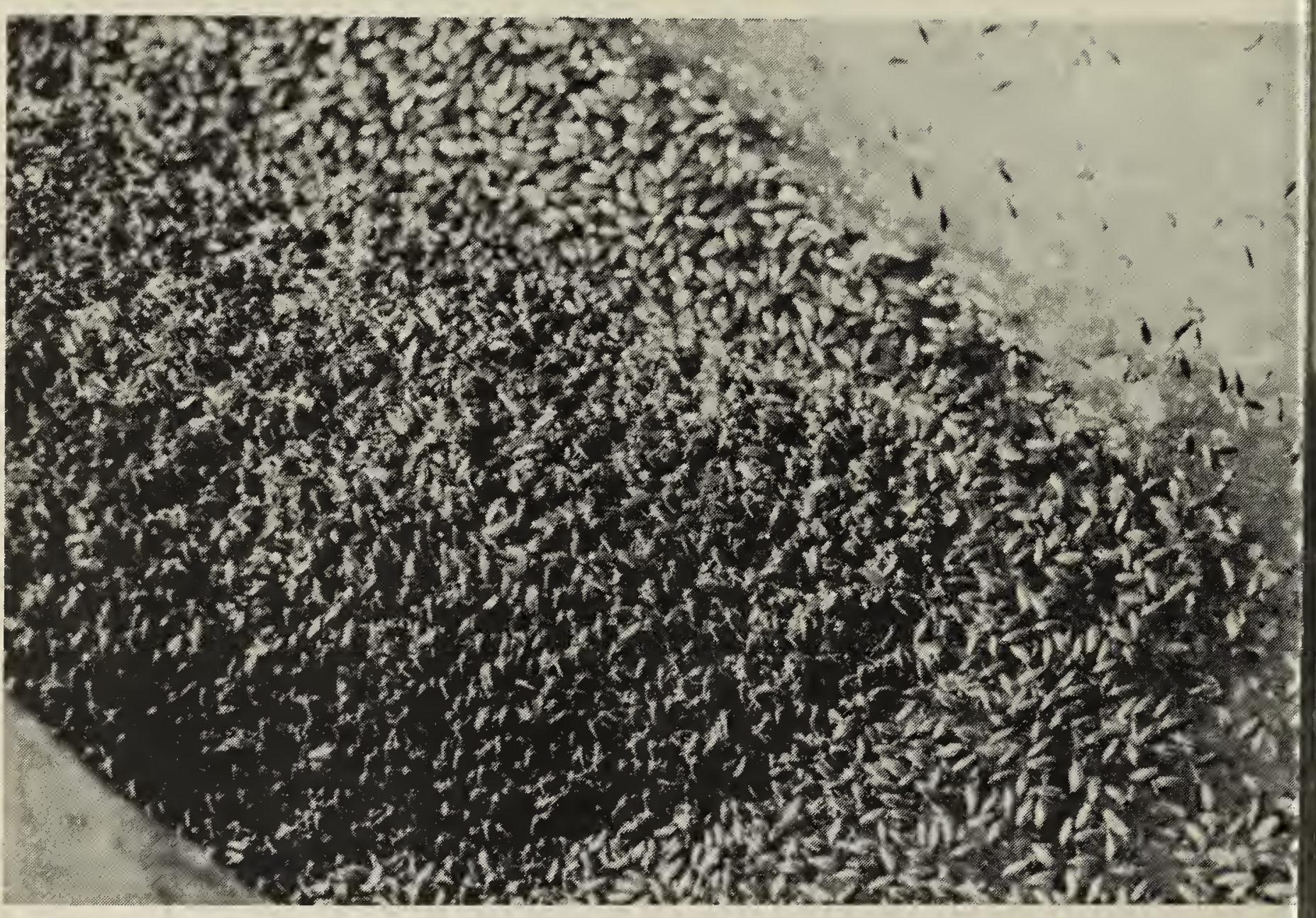

Water boatmen on rock. Blackstrap Reservoir. April 19, 1975.

Bernard Gollop

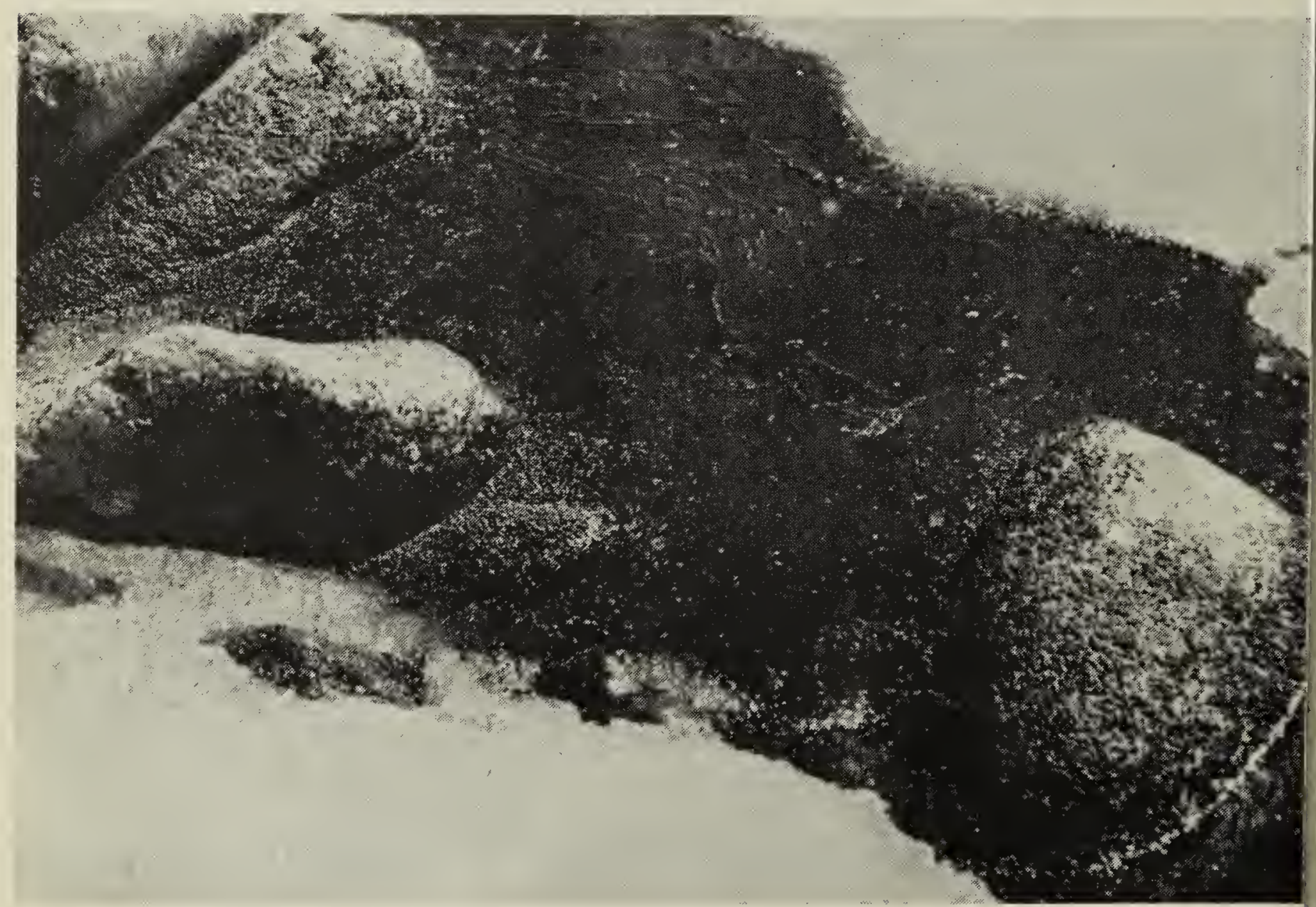

Water boatmen (Corixidae) congregating on water and rocks between snow (foreground on causeway and ice (background) on Blackstrap Reservoir, Saskatchewan, April 19, 1975 Bernard Gollof 